\title{
Diagnosis of Secondary and Micronutrient Deficiencies and Their Management in Rainfed Agroecosystems: Case Study from Indian Semi-arid Tropics
}

\author{
K. L. SAHRAWAT, S. P. WANI, G. PARDHASARADHI, \\ AND K. V. S. MURTHY \\ International Crops Research Institute for the Semi-arid Tropics \\ (ICRISAT), Patancheru, Andhra Pradesh, India
}

\begin{abstract}
Rainfed agriculture in the semi-arid tropical (SAT) regions of India is greatly influenced by water shortages caused by low, highly variable, and erratic rainfall. However, apart from water shortages, crop productivity in these regions is also affected by low fertility. Little effort has been devoted to diagnosing and managing the nutrient-related problems in farmers' fields in the SAT regions of India. The ongoing integrated watershed management program by the International Crops Research Institute for the Semi-arid Tropics and its partners provided the opportunity to diagnose the soil infertility-related problems by soil testing, develop nutrient management protocols, and determine on-farm crop responses to fertilization in the SAT zone of India. This article discusses examples from recent research on the diagnosis of multinutrient deficiencies and on-farm crop responses to fertilization. Results of analyses of soil samples from farmers' fields in several districts of Andhra Pradesh, Karnataka, Tamil Nadu, Rajasthan, and Madhya Pradesh states and Junagarh district, Gujarat, showed that almost all farmers' fields had low organic carbon $(C)$, low to moderate available phosphorus $(P)$, and generally adequate extractable potassium $(K)$. However, the widespread deficiencies of sulfur $(S)$, boron $(B)$, and zinc $(\mathrm{Zn})$ were most revealing; their deficiencies varied with nutrient, district, and state. On-farm trials conducted during three seasons (2002-2004) in three districts of Andhra Pradesh showed significant yield responses of maize, castor, groundnut, and mung bean to the applications of $S, B$, and $\mathrm{Zn}$ over farmer's input treatment, and the yield responses were larger when these nutrients were added along with nitrogen $(N)$ and $P$. It is concluded that the deficiencies of nutrients such as $S, B$, and $Z n$ are widespread and are holding back the potential of rainfed production systems. Clearly, nutrient deficiencies can be diagnosed by soil testing.
\end{abstract}

Keywords Crop productivity, diagnosis of nutrient problems, multinutrient deficiencies, nutrient management, soil testing, water shortage

Received 5 May 2008; accepted 26 August 2009.

Address correspondence to K. L. Sahrawat, International Crops Research Institute for the Semi-arid Tropics (ICRISAT), Patancheru 502 324, Andhra Pradesh, India. E-mail: k.sahrawat@cgiar.org 


\section{Introduction}

Apart from water shortages, soil infertility is the major constraint on crop production and productivity in much of the semi-arid tropical (SAT) regions of the world (El-Swaify et al. 1985; Sahrawat et al. 2007; Bationo et al. 2008). Sulfur (S) and micronutrient deficiencies have been reported with increasing frequency from intensive, irrigated production systems (Kanwar 1972; Takkar, Chhibba, and Mehta 1989; Pasricha and Fox 1993; Takkar 1996; Scherer 2001; Katyal and Rattan 2003), and micronutrient deficiencies have been reported to be one of the main causes for yield plateau or even yield decline in irrigated intensified systems (Takkar 1996; Katyal and Rattan 2003). In the irrigated systems, the nutrient deficiencies have been diagnosed by soil and plant testing and corrected through the fertilization of crops. In contrast, in the SAT regions of India, little attention has been paid to diagnosing the deficiencies of secondary nutrients (such as S) and micronutrients in dryland production systems.

The soil resource base in the Indian SAT is marginal compared with irrigated soils (El-Swaify et al. 1985; Rego et al. 2003). However, it is a commonly held belief that at relatively low yields of crops in the rainfed systems, only deficiencies of major nutrients, especially nitrogen $(\mathrm{N})$ and phosphorus $(\mathrm{P})$, are important for the SAT Indian soils (El-Swaify et al. 1985), and little attention has been devoted to diagnosing the extent of deficiencies of the secondary nutrients (such as S) and micronutrients in various crop production systems (Sahrawat et al. 2007).

It is duly recognized and emphasized that the productivity of SAT soils is low as a result of water shortages. Apart from water shortage, poor fertility is also an issue because poor fertility constraints crop productivity in the SAT regions of India, but in practice the deficiencies of major nutrients $(\mathrm{N}$ and $\mathrm{P})$ are considered important. Moreover, the inputs of major nutrients to dryland production systems are meager. Also, because of low productivity of the drylands, it is generally assumed that the mining of micronutrients reserves in soils is much less than in irrigated production systems (Rego et al. 2003).

For sustained increase in dryland productivity, soil and water conservation measures need to be integrated with plant nutrition, choice of crops, and their management (Wani et al. 2003). The ongoing farmer-participatory integrated watershed management program at the International Crops Research Institute for the Semi-arid Tropics (ICRISAT) provided the opportunity to implement nutrient management strategy with soil and water conservation practices in farmers' fields in the Indian semi-arid tropics. For efficient and judicious use of nutrients through fertilizer inputs, assessing the soil's inherent nutrient status is a prerequisite (Sahrawat 2006).

In an on-farm survey during the 1999 cropping season, it was observed that soil samples collected from the Mili watershed in Lalatora village in Vidisha district of Madhya Pradesh were low in extractable S, boron (B), and zinc ( $\mathrm{Zn}$ ). The results of the follow-up field trial on the application of $\mathrm{B}$ and $\mathrm{Zn}$ significantly increased soybean yields. Taking leads from this preliminary observation, systematic and detailed analysis of soil samples collected from farmers' fields in various ICRISAT watersheds in India was conducted. The objective of this article is to demonstrate how soil test results can be used to diagnose nutrient deficiencies, formulate nutrient management protocols, and evaluate the effects of various nutrient treatments on responses of crops in follow-up trials in farmers' fields with the purpose of 
developing suitable nutrient management strategies for dryland production systems in the SAT regions of India.

\section{Materials and Methods}

\section{Diagnosis of Nutrient Deficiencies by Soil Testing}

To characterize the fertility status of soils under dryland agriculture in the SAT regions of India, we collected 3,622 soil samples from farmers' fields in watersheds, spread in five districts of Andhra Pradesh, five districts of Karnataka, five districts of Tamil Nadu, three districts of Rajasthan, two districts of Madhya Pradesh, and the Junagarh district of Gujarat. The number of farmers cultivating arable land in watersheds (about 500 ha in area) varied along with landholding size and cropping systems (Rego et al. 2007).

For effective sampling, the watersheds were divided into three groups based on the position of the fields on a toposequence: top, middle, and bottom, depending on the elevation and drainage pattern. We separated different soil types in each category. For soil sampling, we randomly selected $20 \%$ of farmers in each position on the toposequence in proportion to the farm size. The soil sampling program of watersheds in various states was undertaken during 2002-2006. (For detailed description of the sites and soil sampling and preparation of the samples for analysis, see Sahrawat et al. 2007.)

Using stratified random sampling (Sahrawat et al. 2008), we collected 8 to 10 cores of surface soils $(0-15 \mathrm{~cm}$ deep) to make one composite sample. The soil samples were air dried and powdered with wooden hammer to pass through a 2-mm sieve. For organic carbon (C) analysis, the soil samples were ground to pass through a $0.25-\mathrm{mm}$ sieve. Prepared samples were analyzed for various fertility characteristics in the ICRISAT Central Analytical Services Laboratory.

For soil analysis, $\mathrm{pH}$ was measured by a glass electrode using a soil-to-water ratio of 1:2. Organic $\mathrm{C}$ was determined using the Walkley-Black method (Nelson and Sommers 1996). Exchangeable potassium (K) was determined using the ammonium acetate method (Helmke and Sparks 1996). Available $\mathrm{S}$ was measured using $0.15 \%$ calcium chloride $\left(\mathrm{CaCl}_{2}\right)$ as an extractant (Tabatabai 1996); available $\mathrm{P}$ was measured using the sodium bicarbonate $\left(\mathrm{NaHCO}_{3}\right)$ test (Olsen and Sommers 1982). Available $\mathrm{Zn}$ was extracted by diethylenetriaminepentaacetic acid (DTPA) reagent (Lindsay and Norvell 1978), and available B was extracted by hot water (Keren 1996).

\section{On-Farm Trials for Evaluating Crop Responses to Fertilization}

During 2002-2004 cropping seasons (June-September), we conducted a number of trials in three districts of Andhra Pradesh using mung bean (Vigna radiata), maize (Zea mays), groundnut (Arachis hypogaea), and castor (Ricinus communis) as test crops; they are the important crops grown in the region. The number of trials with maize was 20 in 2002, 24 in 2003, and 19 in 2004. For castor, the trials were 8 in 2002, 17 in 2003, and 6 in 2004. The trials with groundnut were 19 in 2002, 30 in 2003, and 40 in 2004; for mung bean, there were 9 trials in 2002, 6 in 2003, and 12 in 2004. Each farmer for a crop was treated as a replication. Detailed description of the on-farm trials along with various treatments and crop and nutrient management practices are given in Rego et al. (2007). 
In the first year (2002), farmers' participatory meetings were conducted in all the nine watersheds in three districts. The results of soil analyses were discussed with the respective farmers in group meetings, and 15 volunteer farmers from each watershed were identified to conduct on-farm trials.

In the first year (2002), trials had two treatments: (i) control or farmers' nutrient inputs (termed FI) and (ii) FI + SBZn [(S + B + Zn) applied at $30 \mathrm{~kg} \mathrm{~S}$ plus $0.5 \mathrm{~kg} \mathrm{~B}$ plus $10 \mathrm{~kg} \mathrm{Zn} \mathrm{ha}{ }^{-1}$. We imposed these treatments on $2000-\mathrm{m}^{2}$ plots, side by side. Farmers' crops, varieties, and crop management practices were the same in both the treatments. In the 2003 cropping season, we extended our activities to 50 (10 nucleus plus 40 satellite watersheds) watersheds. We followed the same procedure of soil sampling, analyses, meeting with farmer groups to share and discuss analytical results, and selecting volunteer farmers in the new watersheds. During the 2003 and 2004 seasons, we added one additional treatment consisting of SBZn plus N + P. As in the previous year, each field was considered as one replication. In the 2003 and 2004 trials, the treatments were applied to plots of $1000-\mathrm{m}^{2}$ area, arranged side by side on the same piece of land.

For applying nutrients as per SBZn treatment, we applied S, B, and $\mathrm{Zn}$ via a mixture, which consisted of $200 \mathrm{~kg}$ gypsum $\left(30 \mathrm{~kg} \mathrm{~S}^{-1}\right), 5 \mathrm{~kg}$ borax $(0.5 \mathrm{~kg} \mathrm{~B}$ $\left.\mathrm{ha}^{-1}\right)$, and $50 \mathrm{~kg}$ zinc sulfate $\left(10 \mathrm{~kg} \mathrm{Zn} \mathrm{ha}^{-1}\right) \mathrm{ha}^{-1}$; the mixture was surface broadcast on the plot before the final land preparation. The SBZn $+\mathrm{NP}$ treatment consisted of the same amount of S, B, and $\mathrm{Zn}$ as in SBZn plus $60 \mathrm{~kg}$ $\mathrm{N}$ for maize and castor or $20 \mathrm{~kg} \mathrm{~N}^{-1}$ for groundnut and mung bean; $\mathrm{P}$ was added at $30 \mathrm{~kg} \mathrm{P}_{2} 0_{5}$ ha $^{-1}$. The treatment $\mathrm{SBZn}$ was applied along with $\mathrm{P}$ plus $20 \mathrm{~kg} \mathrm{~N} \mathrm{ha}{ }^{-1}$ as basal to all crops, and $40 \mathrm{~kg} \mathrm{~N} \mathrm{ha}^{-1}$ was top-dressed in the cases of maize and castor. In the case of NP treatment, we applied $20 \mathrm{~kg} \mathrm{~N}$ and $30 \mathrm{~kg} \mathrm{P}_{2} 0_{5} \mathrm{ha}^{-1}$ to all crops as basal and $40 \mathrm{~kg} \mathrm{~N} \mathrm{ha}^{-1}$ as topdressing for maize and castor. Other nutrient treatments (including FI + SBZn and FI + SBZn + NP) were applied as described earlier.

\section{Results and Discussion}

\section{Extent of Nutrient Deficiencies in Farmers' Fields}

It is known that the soils in the SAT regions of India are low in organic matter and that the deficiencies of major nutrients such as $\mathrm{N}$ and $\mathrm{P}$ are common in the production systems on these soils under dryland farming (El-Swaify et al. 1985; Rego et al. 2003; Sahrawat et al. 2007).

The results of the analyses of samples collected from farmers' fields in different watersheds in Andhra Pradesh, Karnataka, Tamil Nadu, Rajasthan, and Madhya Pradesh showed that most of the fields were low in organic $\mathrm{C}$ and low to medium in extractable (available) $\mathrm{P}$ but generally adequate in extractable $\mathrm{K}$. The samples had a range in $\mathrm{pH}$ (see results in Tables 1-5).

Based on our experience at ICRISAT and from published results, the critical limits in the soil used for separating deficient fields from nondeficient field for available (extractable) $\mathrm{S}, \mathrm{B}$, and $\mathrm{Zn}$ are $8-10 \mathrm{mg} \mathrm{kg}^{-1}$ soil $\mathrm{CaCl}_{2}$-extractable $\mathrm{S}$, $0.58 \mathrm{mg} \mathrm{kg}^{-1}$ soil hot water-extractable $\mathrm{B}$, and $0.75 \mathrm{mg} \mathrm{kg}^{-1}$ soil DTPA-extractable $\mathrm{Zn}$ in the soil. We found that field crops grown in fields deficient in $\mathrm{S}, \mathrm{B}$, and $\mathrm{Zn}$, as per the critical limits for $\mathrm{S}, \mathrm{B}$, and $\mathrm{Zn}$ in the soil, gave significant yield responses to the applications of these nutrients (Rego et al. 2005, 2007). 
Table 1. Chemical characteristics of soil samples (1926) collected from farmers' fields in five districts of Andhra Pradesh, 2002-2004 (from Sahrawat et al. 2007)

\begin{tabular}{|c|c|c|c|c|c|c|c|c|c|}
\hline \multirow[b]{2}{*}{ District } & \multirow{2}{*}{$\begin{array}{l}\text { No. of } \\
\text { Fields }\end{array}$} & \multirow[b]{2}{*}{ Parameter } & \multirow[b]{2}{*}{$\mathrm{pH}$} & \multirow{2}{*}{$\begin{array}{c}\text { Organic C } \\
(\%)\end{array}$} & \multirow{2}{*}{$\begin{array}{c}\text { Olsen P } \\
\left(\mathrm{mg} \mathrm{kg}^{-1}\right)\end{array}$} & \multirow{2}{*}{$\begin{array}{c}\text { Exch. K } \\
\left(\mathrm{mg} \mathrm{kg}^{-1}\right)\end{array}$} & \multicolumn{3}{|c|}{ Extractable nutrient elements $\left(\mathrm{mg} \mathrm{kg}^{-1}\right)$} \\
\hline & & & & & & & $\mathrm{S}$ & B & $\mathrm{Zn}$ \\
\hline \multirow[t]{3}{*}{ Nalgonda } & 256 & Range & $5.7-9.2$ & $0.12-1.36$ & $0.7-24.9$ & 34-359 & $1.4-24.9$ & $0.02-1.48$ & $0.08-16.0$ \\
\hline & & Mean & 7.7 & 0.40 & 8.1 & 132 & 5.9 & 0.26 & 0.73 \\
\hline & & $\%$ deficient $^{a}$ & & & & & 86 & 93 & 73 \\
\hline \multirow{3}{*}{$\begin{array}{l}\text { Mahabubnag- } \\
\text { ar }\end{array}$} & 358 & Range & $5.5-9.1$ & $0.08-1.20$ & $0.7-61.0$ & $25-487$ & $1.2-98$ & $0.02-1.62$ & $0.12-35.60$ \\
\hline & & Mean & 7.1 & 0.36 & 9.1 & 117 & 9.4 & 0.22 & 1.34 \\
\hline & & $\%$ deficient & & & & & 73 & 94 & 62 \\
\hline \multirow[t]{3}{*}{ Kurnool } & 309 & Range & $5.6-9.7$ & $0.09-1.06$ & $0.4-31.5$ & 33-508 & $1.4-26.9$ & $0.04-1.64$ & $0.08-4.92$ \\
\hline & & Mean & 7.8 & 0.34 & 7.8 & 142 & 5.3 & 0.34 & 0.42 \\
\hline & & $\%$ deficient & & & & & 88 & 83 & 94 \\
\hline \multirow[t]{3}{*}{ Ananthapur } & 511 & Range & 5.4-9.6 & $0.12-0.8$ & $0.7-39.5$ & 14-282 & $0.2-67.9$ & $0.02-0.68$ & $0.08-2.2$ \\
\hline & & Mean & 7.5 & 0.28 & 7.6 & 70 & 3.6 & 0.20 & 0.55 \\
\hline & & $\%$ deficient & & & & & 95 & 100 & 86 \\
\hline \multirow[t]{6}{*}{ Prakasam } & 492 & Range & $5.6-9.7$ & $0.09-1.3$ & $0.2-41.7$ & $28-697$ & $0.5-19.2$ & $0.02-1.86$ & $0.2-3.52$ \\
\hline & & Mean & 7.8 & 0.43 & 5.7 & 205 & 4.1 & 0.45 & 0.51 \\
\hline & & $\%$ deficient & & & & & 94 & 70 & 88 \\
\hline & 1926 & Range & $5.4-9.7$ & $0.08-1.36$ & $0.20-61.00$ & $14-697$ & $0.23-98.0$ & $0.02-1.86$ & $0.08-35.60$ \\
\hline & & Mean & 7.7 & 0.36 & 7.54 & 133 & 5.6 & 0.30 & 0.71 \\
\hline & & $\%$ deficient & & & & & 89 & 88 & 82 \\
\hline
\end{tabular}

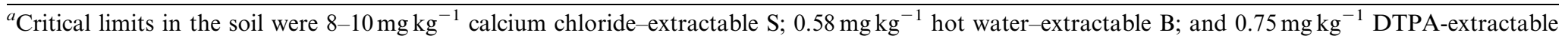
$\mathrm{Zn}$. 
Table 2. Chemical characteristics of soil samples (1260) collected from farmers' fields in five districts of Karnataka, 2005-2006 (from Sahrawat et al. 2007)

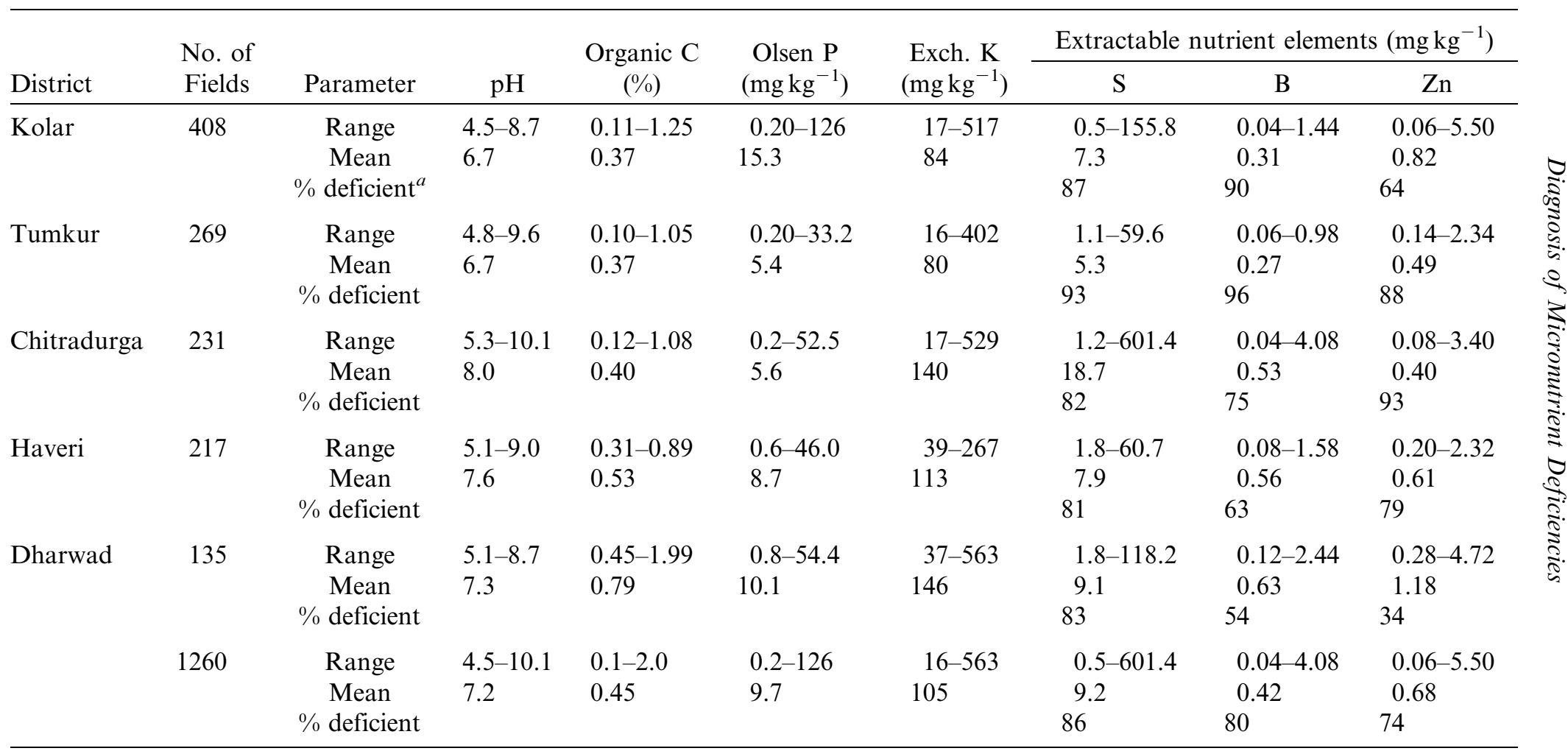

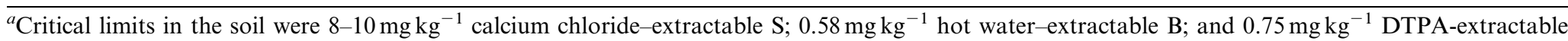
$\mathrm{Zn}$. 
Table 3. Chemical characteristics of soil samples (179) collected from farmers' fields in three districts of Rajasthan, $2003-2006$ (from Sahrawat et al. 2007)

\begin{tabular}{|c|c|c|c|c|c|c|c|c|c|}
\hline \multirow[b]{2}{*}{ District } & \multirow{2}{*}{$\begin{array}{l}\text { No. of } \\
\text { Fields }\end{array}$} & \multirow[b]{2}{*}{ Parameter } & \multirow[b]{2}{*}{$\mathrm{pH}$} & \multirow{2}{*}{$\begin{array}{c}\text { Organic C } \\
(\%)\end{array}$} & \multirow{2}{*}{$\begin{array}{c}\text { Olsen P } \\
\left(\mathrm{mg} \mathrm{kg}^{-1}\right)\end{array}$} & \multirow{2}{*}{$\begin{array}{c}\text { Exch. K } \\
\left(\mathrm{mg} \mathrm{kg}^{-1}\right)\end{array}$} & \multicolumn{3}{|c|}{ Extractable nutrient elements $\left(\mathrm{mg} \mathrm{kg}^{-1}\right)$} \\
\hline & & & & & & & $\mathrm{S}$ & $\mathrm{B}$ & $\mathrm{Zn}$ \\
\hline \multirow[t]{3}{*}{ Bundi } & 36 & Range & $6.2-8.7$ & $0.18-1.17$ & $0.9-20.1$ & $23-563$ & $3.3-51.0$ & $0.1-0.98$ & $0.2-1.8$ \\
\hline & & Mean & 7.6 & 0.60 & 6.2 & 87 & 9.2 & 0.44 & 0.60 \\
\hline & & $\%$ deficient $^{a}$ & & & & & 72 & 72 & 67 \\
\hline \multirow[t]{3}{*}{ Dungarpur } & 99 & Range & $6.2-8.0$ & $0.48-1.99$ & $1.0-28.2$ & $34-240$ & $4.0-31.3$ & $0.28-1.50$ & $0.88-14.10$ \\
\hline & & Mean & 6.9 & 1.26 & 6.6 & 100 & 9.0 & 0.70 & 2.11 \\
\hline & & $\%$ deficient & & & & & 72 & 31 & 0 \\
\hline \multirow[t]{6}{*}{ Udaipur } & 44 & Range & $7.3-9.0$ & $0.25-2.37$ & $2.6-41.0$ & $52-288$ & $3.2-274$ & $0.22-1.50$ & $0.70-3.92$ \\
\hline & & Mean & 8.2 & 0.83 & 15.2 & 145 & 26.7 & 0.83 & 1.57 \\
\hline & & $\%$ deficient & & & & & 48 & 25 & 05 \\
\hline & 179 & Range & $6.2-9.0$ & $0.2-2.4$ & $0.9-41.0$ & $23-563$ & $3.2-274$ & $0.10-1.50$ & $0.20-14.1$ \\
\hline & & Mean & 7.4 & 1.02 & 8.6 & 108 & 13.4 & 0.68 & 1.68 \\
\hline & & $\%$ deficient & & & & & 66 & 38 & 15 \\
\hline
\end{tabular}

${ }^{a}$ Critical limits in the soil were $8-10 \mathrm{mg} \mathrm{kg}^{-1}$ calcium chloride-extractable S; $0.58 \mathrm{mg} \mathrm{kg}^{-1}$ hot water-extractable B; and $0.75 \mathrm{mg} \mathrm{kg}^{-1}$ DTPA-extractable $\mathrm{Zn}$. 
Table 4. Chemical characteristics of soil samples (55) collected from farmers' fields in two districts of Madhya Pradesh, 2002-2004 (from Sahrawat et al. 2007)

\begin{tabular}{|c|c|c|c|c|c|c|c|c|c|}
\hline \multirow[b]{2}{*}{ District } & \multirow{2}{*}{$\begin{array}{l}\text { No. of } \\
\text { Fields }\end{array}$} & \multirow[b]{2}{*}{ Parameter } & \multirow[b]{2}{*}{$\mathrm{pH}$} & \multirow{2}{*}{$\begin{array}{c}\text { Organic C } \\
(\%)\end{array}$} & \multirow{2}{*}{$\begin{array}{c}\text { Olsen P } \\
\left(\mathrm{mg} \mathrm{kg}^{-1}\right)\end{array}$} & \multirow{2}{*}{$\begin{array}{c}\text { Exch. K } \\
\left(\mathrm{mg} \mathrm{kg}^{-1}\right)\end{array}$} & \multicolumn{3}{|c|}{ Extractable nutrient elements $\left(\mathrm{mg} \mathrm{kg}^{-1}\right)$} \\
\hline & & & & & & & $\mathrm{S}$ & $\mathrm{B}$ & $\mathrm{Zn}$ \\
\hline \multirow[t]{3}{*}{ Vidisha } & 31 & Range & $7.6-8.3$ & $0.46-0.92$ & $0.5-14.1$ & $97-285$ & $2.9-9.8$ & $0.12-0.34$ & $0.10-0.42$ \\
\hline & & Mean & 8.1 & 0.64 & 2.7 & 212 & 5.1 & 0.2 & 0.23 \\
\hline & & $\%$ deficient $^{a}$ & & & & & 100 & 100 & 100 \\
\hline \multirow[t]{6}{*}{ Dewas } & 24 & Range & $7.0-8.7$ & $0.3-1.0$ & $0.2-10.8$ & $46-456$ & $3.9-9.5$ & $0.2-0.8$ & $0.12-0.56$ \\
\hline & & Mean & 8.0 & 0.60 & 2.1 & 137 & 6.3 & 0.5 & 0.24 \\
\hline & & $\%$ deficient & & & & & 100 & 96 & 100 \\
\hline & 55 & Range & $7.0-8.7$ & $0.31-1.00$ & $0.20-14.1$ & 46-456 & $2.90-9.75$ & $0.12-0.56$ & $0.10-0.82$ \\
\hline & & Mean & 8.1 & 0.62 & 2.43 & 179 & 5.63 & 0.22 & 0.33 \\
\hline & & $\%$ deficient & & & & & 100 & 100 & 98 \\
\hline
\end{tabular}

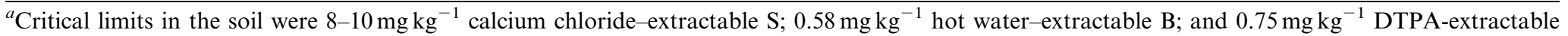
$\mathrm{Zn}$. 
Table 5. Chemical characteristics of soil samples (119) collected from farmers' fields in five districts of Tamil Nadu, $2004-2006$ (from Sahrawat et al. 2007)

\begin{tabular}{|c|c|c|c|c|c|c|c|c|c|}
\hline \multirow[b]{2}{*}{ District } & \multirow{2}{*}{$\begin{array}{l}\text { No. of } \\
\text { Fields } \\
\end{array}$} & \multirow[b]{2}{*}{ Parameter } & \multirow[b]{2}{*}{$\mathrm{pH}$} & \multirow{2}{*}{$\begin{array}{c}\text { Organic C } \\
(\%)\end{array}$} & \multirow{2}{*}{$\begin{array}{c}\text { Olsen P } \\
\left(\mathrm{mg} \mathrm{kg}^{-1}\right)\end{array}$} & \multirow{2}{*}{$\begin{array}{c}\text { Exch. K } \\
\left(\mathrm{mg} \mathrm{kg}^{-1}\right)\end{array}$} & \multicolumn{3}{|c|}{ Extractable nutrient elements $\left(\mathrm{mg} \mathrm{kg}^{-1}\right)$} \\
\hline & & & & & & & $\mathrm{S}$ & $\mathrm{B}$ & $\mathrm{Zn}$ \\
\hline Tirunelveli & 39 & $\begin{array}{c}\text { Range } \\
\text { Mean } \\
\% \text { deficient }^{a}\end{array}$ & $\begin{array}{l}4.8-8.7 \\
6.7\end{array}$ & $\begin{array}{l}0.15-0.74 \\
0.39\end{array}$ & $\begin{array}{l}0.2-26.8 \\
5.5\end{array}$ & $\begin{array}{l}34-255 \\
98\end{array}$ & $\begin{array}{l}1.0-19.7 \\
4.2 \\
97\end{array}$ & $\begin{array}{l}0.06-0.58 \\
0.23 \\
97\end{array}$ & $\begin{array}{l}0.18-2.86 \\
0.62 \\
72\end{array}$ \\
\hline Salem & 20 & $\begin{array}{c}\text { Range } \\
\text { Mean } \\
\% \text { deficient }\end{array}$ & $\begin{array}{l}5.8-8.9 \\
7.9\end{array}$ & $\begin{array}{l}0.14-1.37 \\
0.56\end{array}$ & $\begin{array}{l}1.0-40.4 \\
13.2\end{array}$ & $\begin{array}{l}29-438 \\
141\end{array}$ & $\begin{array}{l}3.6-93.6 \\
15.7 \\
60\end{array}$ & $\begin{array}{l}0.14-0.48 \\
0.27 \\
100\end{array}$ & $\begin{array}{l}0.22-2.86 \\
0.90 \\
45\end{array}$ \\
\hline $\begin{array}{l}\text { Kanchipura- } \\
\mathrm{m}\end{array}$ & 20 & $\begin{array}{c}\text { Range } \\
\text { Mean } \\
\% \text { deficient }\end{array}$ & $\begin{array}{l}5.6-9.4 \\
7.6\end{array}$ & $\begin{array}{l}0.19-1.06 \\
0.48\end{array}$ & $\begin{array}{l}0.8-27.0 \\
7.0\end{array}$ & $\begin{array}{l}13-108 \\
45\end{array}$ & $\begin{array}{l}1.6-51.7 \\
10.9 \\
70\end{array}$ & $\begin{array}{l}0.10-0.60 \\
0.34 \\
85\end{array}$ & $\begin{array}{l}0.28-1.46 \\
0.78 \\
55\end{array}$ \\
\hline Vellore & 20 & $\begin{array}{l}\text { Range } \\
\text { Mean } \\
\% \text { deficient }\end{array}$ & $\begin{array}{l}6.6-9.1 \\
8.5\end{array}$ & $\begin{array}{l}0.19-0.97 \\
0.62\end{array}$ & $\begin{array}{l}1.2-67.2 \\
14.6\end{array}$ & $\begin{array}{l}24-585 \\
115\end{array}$ & $\begin{array}{l}4.1-42.3 \\
13.9 \\
55\end{array}$ & $\begin{array}{l}0.12-1.02 \\
0.35 \\
90\end{array}$ & $\begin{array}{l}0.24-2.20 \\
0.81 \\
65\end{array}$ \\
\hline Karur & 20 & $\begin{array}{l}\text { Range } \\
\text { Mean } \\
\% \text { deficient }\end{array}$ & $\begin{array}{l}6.1-8.8 \\
8.0\end{array}$ & $\begin{array}{l}0.10-2.29 \\
0.63\end{array}$ & $\begin{array}{l}1.3-26.2 \\
9.2\end{array}$ & $\begin{array}{l}54-690 \\
235\end{array}$ & $\begin{array}{l}2.4-83.5 \\
18.6 \\
50\end{array}$ & $\begin{array}{l}0.06-2.18 \\
0.62 \\
65\end{array}$ & $\begin{array}{l}0.26-5.12 \\
0.94 \\
60\end{array}$ \\
\hline & 119 & $\begin{aligned} & \text { Range } \\
& \text { Mean } \\
\% & \text { deficient }\end{aligned}$ & $\begin{array}{l}4.8-9.4 \\
7.6\end{array}$ & $\begin{array}{l}0.08-1.36 \\
0.51\end{array}$ & $\begin{array}{l}0.20-67.2 \\
9.2\end{array}$ & $\begin{array}{l}13-690 \\
122\end{array}$ & $\begin{array}{l}1.0-93.6 \\
11.3 \\
85\end{array}$ & $\begin{array}{l}0.10-2.20 \\
0.34 \\
89\end{array}$ & $\begin{array}{l}0.20-5.10 \\
0.78 \\
61\end{array}$ \\
\hline
\end{tabular}

${ }^{a}$ Critical limits in the soil were $8-10 \mathrm{mg} \mathrm{kg}^{-1}$ calcium chloride-extractable S; $0.58 \mathrm{mg} \mathrm{kg}^{-1}$ hot water-extractable B; and $0.75 \mathrm{mg} \mathrm{kg}^{-1}$ DTPA-extractable Zn. 
In five districts of Andhra Pradesh, of the 1,926 farmers' fields sampled, $89 \%$ were deficient in available S, 88\% were deficient in available $\mathrm{B}$, and $82 \%$ were deficient in available $\mathrm{Zn}$ (Table 1). In the light of these results, it is not surprising that application of S, B, and $\mathrm{Zn}$ significantly increased crop yields in on-farm studies (Rego et al. 2007). However, under rainfed farming in the SAT regions, the crop yield responses to added nutrients are greatly influenced and modified by the rainfall received and its distribution during the growing season (El-Swaify et al. 1985; Rego et al. 2003, 2005).

In five districts of Karnataka, the deficiency of $\mathrm{S}$ ( $86 \%$ farmers' fields) was most widespread, followed by B $(80 \%)$ and $\mathrm{Zn}(74 \%)$ (see results in Table 2$)$. In some farmers' fields, very high values of extractable or available $\mathrm{S}$ were recorded as a result of the presence of free gypsum (calcium sulfate, $\mathrm{CaSO}_{4}$ ) in the soil profile.

The results of the analysis of 179 soils collected from farmers' fields in Bundi, Dungarpur, and Udaipur districts of Rajasthan showed that $66 \%$ fields were deficient in available S, 38\% in B, and 15\% in $\mathrm{Zn}$ (Table 3). Some soil samples had high values of extractable $\mathrm{S}$ because of the presence of gypsum (calcium sulfate, $\mathrm{CaSO}_{4}$ ) in the soil. The results of soil analysis from the farmers' fields in the SAT districts of Rajasthan showed that the deficiencies of S, B, and $\mathrm{Zn}$ were not as widespread as in the case of soil samples collected from the watersheds in Madhya Pradesh, Andhra Pradesh, and Karnataka.

The results of the analysis of soil samples collected from 55 farmers' fields from Vidisha and Dewas districts in Madhya Pradesh revealed that $100 \%$ of the fields were deficient in S, 96-100\% were deficient in B, and $98-100 \%$ were deficient in $\mathrm{Zn}$ (Table 4).

The variability in extractable or available $\mathrm{S}, \mathrm{B}$, and $\mathrm{Zn}$ in soil samples collected from 119 farmers' fields in five districts of the Tamil Nadu state was rather large (Table 5). The number of farmers' fields deficient in extractable $\mathrm{S}$ varied from $50 \%$ (Karur district) to $97 \%$ (Tirunelveli district); the extent of occurrence of B deficiency in the five districts varied from $65 \%$ (Karur) to $100 \%$ (Salem). In general, the occurrence of $\mathrm{Zn}$ deficiency in the five districts was less than those of S and B, and it varied from $45 \%$ (Salem) to $72 \%$ (Tirunelveli). On average, $85 \%$ of the farmers' fields were deficient in extractable S, $89 \%$ were deficient in available B, and $61 \%$ were deficient in available $\mathrm{Zn}$ (Table 5).

In the Junagarh district, Gujarat, of the soil samples collected from 82 farmers' fields, $46 \%$ of fields were deficient in available $\mathrm{S}, 100 \%$ were deficient in available $\mathrm{B}$, and $82 \%$ were deficient in available $\mathrm{Zn}$. The results showed that B deficiency was most prevalent, followed by Zn and S deficiency (Sahrawat et al. 2007).

\section{Responses of Crops to Fertilization in Farmers' Fields}

Since 2000, a large number of on-farm nutrient management trials have been conducted in ICRISAT-managed watersheds in the SAT regions of India to study yield responses of crops to the applications of nutrients found to be deficient based on soil tests and to develop appropriate nutrient management practices for enhancing the productivity of rainfed systems. The results of these initial studies are summarized in an earlier publication (Rego et al. 2005). The results showed widespread deficiencies of S, B, and $\mathrm{Zn}$ in farmers' fields; crop yields significantly increased as a result of the applications of these nutrients over farmer's inputs treatment (Rego et al. 2005). 
In this article, we discuss the salient results from more recent on-farm trials conducted consecutively for three seasons (2002-2004) in watersheds spread in three districts of Andhra Pradesh. The results presented are typical of crop responses obtained to the applications of deficient nutrients (,$B$, and $\mathrm{Zn}$ ) as compared to farmer's inputs.

Maize. For the maize trials, compared to the FI (farmer's inputs) treatment, the applications of FI + SBZn and FI + SBZn + NP nutrient treatments significantly increased grain yield and total biomass of maize during the three seasons of experimentation (Table 6). In the 2002 season, SBZn treatment on average yielded $67 \%$ more grain and $24 \%$ more stover than the FI treatment. Similar significant yield $(\mathrm{p}<0.05)$ responses were obtained in the 2003 (48 and $37 \%$ increase in grain and

Table 6. Yields of maize and castor in response to fertilization in Andhra Pradesh, 2002-2004 (from Rego et al. 2007)

\begin{tabular}{|c|c|c|c|}
\hline Year & Treatment & Grain yield $\left(\mathrm{kg} \mathrm{ha}^{-1}\right)$ & Total dry matter $\left(\mathrm{kg} \mathrm{ha}^{-1}\right)$ \\
\hline
\end{tabular}

2002

2003

Farmer inputs (FI)

$\mathrm{FI}+\mathrm{SBZn}$

$\operatorname{LSD}(0.05)$

FI

$\mathrm{FI}+\mathrm{SBZn}$

$\mathrm{FI}+\mathrm{SBZn}+\mathrm{NP}$

LSD (0.05)

2004

FI

$\mathrm{FI}+\mathrm{SBZn}$

$\mathrm{FI}+\mathrm{SBZn}+\mathrm{NP}$

LSD (0.05)

\section{Castor}

2002

2003

Farmer inputs FI

$\mathrm{FI}+\mathrm{SBZn}$

LSD (0.05)

FI

$\mathrm{FI}+\mathrm{SBZn}$

$\mathrm{FI}+\mathrm{SBZn}+\mathrm{NP}$

LSD (0.05)

2004

FI

$\mathrm{FI}+\mathrm{SBZn}$

$\mathrm{FI}+\mathrm{SBZn}+\mathrm{NP}$

LSD (0.05)
2730

4560

419

2790

4130

4880

271

2430

3110

4230

417

590

890

143

690

1000

1190

186

990

1240

1370

285
6200

8850

633

6370

9040

10377

580

5820

7060

9470

1054

1400

2070

360

1610

2270

2770

403

2220

2710

3350

484 
stover, respectively) and 2004 (28 and 16\% increase in grain and stover, respectively) cropping seasons. In the 2003 and 2004 seasons, the addition of $\mathrm{N}$ and $\mathrm{P}$ along with SBZn resulted in 75 and $74 \%$ more grain yield and 53 and $55 \%$ more stover yield, respectively. From the results of trials conducted in the 2004 season, the SBZn treatment gave $680 \mathrm{~kg} \mathrm{ha}^{-1}$ more grain yield compared to the FI treatment. Similarly, $540 \mathrm{~kg} \mathrm{ha}^{-1}$ extra stover yield were obtained by the application of SBZn over the FI treatment.

Castor. Application of nutrient combinations, SBZn or SBZn + NP, over the FI treatment significantly increased pod and total biomass of the castor crop in all the three seasons of evaluation (Table 6). Compared to the FI treatment, FI + SBZn produced 300, 310, and $250 \mathrm{~kg} \mathrm{ha}^{-1}$ more pods during the 2002, 2003, and 2004 seasons, respectively. Nutrient treatment FI + SBZn + NP produced 190 and $130 \mathrm{~kg} \mathrm{ha}^{-1}$ more pods than FI + SBZn treatment in 2003 and 2004 seasons, respectively. In the 2004 season, castor produced more pod yield in FI + SBZn + NP than other treatments. The stalk and biomass yields also responded to applied SBZn and SBZn + NP as compared to the FI treatment during 2002-2004 (Table 6).

Groundnut. Groundnut pod and biomass yields were significantly $(\mathrm{p}<0.05)$ increased by the application of various nutrient treatments (FI + SBZn and FI + $\mathrm{SBZn}+\mathrm{NP}$ ) as compared to the FI treatment; highest responses were obtained in the SBZn + NP treatment in all the three seasons (Table 7). Percentage increase in pod yields due to the application of SBZn over the FI treatment were 33, 48, and 29 during 2002, 2003, and 2004, respectively. In the 2003 and 2004 cropping seasons, the treatment FI + SBZn + NP produced $79 \%$ and $39 \%$ more pod yields than the FI treatment. The groundnut haulm and biomass yields were also significantly $(\mathrm{p}<$ 0.05 ) increased by FI + SBZn and FI + SBZn + NP treatments. The increases in pod yields were 240,250 , and $270 \mathrm{~kg} \mathrm{ha}^{-1}$ as a result of application of SBZn over the FI treatment during 2002, 2003, and 2004, respectively. In the 2003 and 2004 seasons, 420 and $360 \mathrm{~kg} \mathrm{ha}^{-1}$ more pod yields were obtained because of the application of SBZn + NP treatment over the FI treatment.

Mung Bean. During the three seasons, the grain and total biomass yields of the mung bean crop were significantly $(\mathrm{p}<0.05)$ increased as a result of the application of various nutrient combinations (FI + SBZn and FI + SBZn + NP) as compared to the FI treatment (Table 7). The grain yield responses to the application of FI + SBZn treatment were 43,54 , and $24 \%$ larger compared to those in the FI treatment during 2002, 2003, and 2004, respectively; the haulm yield responses for these seasons were respectively 38, 72, and 10\% larger than in the FI treatment in those years. In the 2004 season, FI + SBZn treatment gave $180 \mathrm{~kg} \mathrm{ha}^{-1}$ more grain yield than the FI treatment, whereas $420 \mathrm{~kg} \mathrm{ha}^{-1}$ more grain yield was obtained in the FI $+\mathrm{SBZn}+$ NP treatment as compared to the FI treatment (Table 7).

\section{Conclusions}

The results presented in this article along with our recent research show that although water shortage greatly affects crop production and productivity in rainfed areas in the SAT regions of India, widespread deficiencies of nutrients such as S, B, and $\mathrm{Zn}$ are also holding back productivity of rainfed systems, resulting in low water- 
Table 7. Yields of groundnut and mung bean in response to fertilization in Andhra Pradesh, 2002-2004 (from Rego et al., 2007)

\begin{tabular}{|c|c|c|c|}
\hline Year & Treatments & Grain yield $\left(\mathrm{kg} \mathrm{ha}^{-1}\right)$ & Total dry matter $\left(\mathrm{kg} \mathrm{ha}^{-1}\right)$ \\
\hline
\end{tabular}

2002

\section{Groundnut}

$\begin{array}{lrr}\text { Farmer inputs (FI) } & 700 & 2690 \\ \text { FI }+ \text { SBZn } & 940 & 3420 \\ \text { LSD }(0.05) & 103 & 145\end{array}$

2003

$\begin{array}{lrr}\text { FI } & 560 & 2920 \\ \text { FI }+ \text { SBZn } & 810 & 4150 \\ \text { FI }+ \text { SBZn }+ \text { NP } & 980 & 4740 \\ \text { LSD }(0.05) & 59 & 183\end{array}$

2004

$\begin{array}{lrr}\text { FI } & 920 & 4080 \\ \text { FI }+ \text { SBZn } & 1190 & 4930 \\ \text { FI }+ \text { SBZn }+ \text { NP } & 1280 & 5060 \\ \text { LSD }(0.05) & 96 & 262\end{array}$

2002

\section{Mung bean}

Farmer inputs FI

$$
\operatorname{LSD}(0.05)
$$

2003

$\begin{array}{lrr}\text { FI } & 900 & 2900 \\ \text { FI }+ \text { SBZn } & 1390 & 4840 \\ \text { FI }+ \text { SBZn }+ \text { NP } & 1540 & 5420 \\ \text { LSD }(0.05) & 160 & 417\end{array}$

2004

$\begin{array}{lrr}\text { FI } & 740 & 2800 \\ \text { FI }+ \text { SBZn } & 920 & 3200 \\ \text { FI }+ \text { SBZn }+ \text { NP } & 1160 & 4050 \\ \text { LSD }(0.05) & 131 & 580\end{array}$

use efficiency. Equally important are the demonstration and confirmation of the crucial role soil testing can play to diagnose nutrient deficiencies, leading to judicious use of nutrient inputs in various production systems. Obviously, there is an urgent need to strengthen the soil testing program for diagnosing emerging nutrient disorders and for determining nutrient sufficiency and requirements (Black 1993; Mills and Jones 1996; Sahrawat 2006), leading to judicious and efficient use of nutrient inputs in rainfed systems at the local and regional levels. The results from soil testing should be shared with and used by farmers to make dryland agriculture more efficient through balanced plant nutrition and improved rainwater-use efficiency. For sustainable increase in dryland productivity, the implementation of soil and water conservation practices along with judicious and balanced use of plant nutrient is required. 


\section{Acknowledgments}

We thank the Andhra Pradesh Rural Livelihood Program (APRLP) of the government of Andhra Pradesh, the Department for International Development (DFID), the World Bank Special Fund for Watershed Development, the government of Karnataka, the Sir Dorabji Tata Trust, and the Asian Development Bank for the financial support of various projects under which the studies were undertaken. We are also grateful to all farmers who participated in these studies.

\section{References}

Bationo, A., J. Kihara, B. Vanlauwe, J. Kimetu, B. S. Waswa, and K. L. Sahrawat. 2008. Integrated nutrient management: Concepts and experience from Sub-Saharan Africa. In Integrated nutrient management for sustainable crop production, ed. M. S. Aulakh and C. A. Grant, 467-521. New York: Haworth Press.

Black, C. A. 1993. Soil fertility evaluation and control, 155-452. Boca Raton, Fl.: Lewis Publishers.

El-Swaify, S. A., P. Pathak, T. J. Rego, and S. Singh. 1985. Soil management for optimized productivity under rainfed conditions in the semi-arid tropics. Advances in Soil Science $1: 1-64$.

Helmke, P. A., and D. L. Sparks. 1996. Lithium, sodium, potassium, rubidium, and cesium. In Methods of soil analysis, part 3: Chemical methods (Soil Science Society of America Book Series No. 5), ed. D. L. Sparks, 551-574. Madison, Wisc.: SSSA and ASA.

Kanwar, J. S. 1972. Twenty-five years of research in soil, fertilizer, and water management in India. Indian Farming 22 (5): 16-25.

Katyal, J. C., and R. K. Rattan. 2003. Secondary and micronutrients: Research gaps and future needs. Fertilizer News 48 (4): 9-14, 17-20.

Keren, R. 1996. Boron. In Methods of soil analysis, part 3: Chemical methods (Soil Science Society of America Book Series No. 5), ed. D. L. Sparks, 603-626. Madison, Wisc.: SSSA and ASA.

Lindsay, W. L., and W. A. Norvell. 1978. Development of a DTPA test for zinc, iron, manganese, and copper. Soil Science Society of America Journal 42:421-428.

Mills, H. A., and J. B. Jones Jr. 1996. Plant analysis handbook: A practical sampling, preparation, and interpretation guide. Athens, Ga.: Micro Macro Publishing, Inc.

Nelson, D. W., and L. E. Sommers. 1996. Total carbon, organic carbon, and organic matter. In Methods of soil analysis, part 3: Chemical methods (Soil Science Society of America Book Series No. 5), ed. D. L. Sparks, 961-1010. Madison, Wisc.: SSSA and ASA.

Olsen, S. R., and L. E. Sommers. 1982. Phosphorus. In Methods of soil analysis, part 2, 2nd ed. (Agronomy Monograph 9), ed. A. L. Page, 403-430. Madison, Wisc.: ASA and SSSA.

Pasricha, N. S., and R. L. Fox. 1993. Plant nutrient sulfur in the tropics and subtropics. Advances in Agronomy 50:209-269.

Rego, T. J., V. N. Rao, B. Seeling, G. Pardhasaradhi, and J. V. D. K. Kumar Rao. 2003. Nutrient balances-A guide to improving sorghum and groundnut-based dryland cropping systems in semi-arid tropical India. Field Crops Research 81:53-68.

Rego, T. J., K. L. Sahrawat, S. P. Wani, and G. Pardhasaradhi. 2007. Widespread deficiencies of sulfur, boron, and zinc in Indian semi-arid tropical soils: On-farm crop responses. Journal of Plant Nutrition 30:1569-1583.

Rego, T. J., S. P. Wani, K. L. Sahrawat, and G. Pardhasaradhi. 2005. Macro-benefits from boron, zinc and sulfur application in Indian SAT: A step for gray to green revolution in agriculture (Global Theme on Agroecosystems Report No.16). Patancheru, Andhra Pradesh, India: International Crops Research Institute for the Semi-Arid Tropics.

Sahrawat, K. L. 2006. Plant nutrients: Sufficiency and requirements. In Encyclopedia of soil science, 2nd ed., ed. R. Lal, 1306-1310. Philadelphia: Taylor and Francis. 
Sahrawat, K. L., T. J. Rego, S. P. Wani, and G. Pardhasaradhi. 2008. Stretching soil sampling to watershed: Evaluation of soil-test parameters in a semi-arid tropical watershed. Communications in Soil Science and Plant Analysis 39:2950-2960.

Sahrawat, K. L., S. P. Wani, T. J. Rego, G. Pardhasaradhi, and K. V. S. Murthy. 2007. Widespread deficiencies of sulfur, boron, and zinc in dryland soils of the Indian semi-arid tropics. Current Science 93:1428-1432.

Scherer, N. W. 2001. Sulfur in crop production. European Journal of Agronomy 14:81-111.

Tabatabai, M. A. 1996. Sulfur. In Methods of soil analysis, part 3: Chemical methods (Soil Science Society of America Book Series No. 5), ed. D. L. Sparks, 921-960. Madison, Wisc.: SSSA and ASA.

Takkar, P. N. 1996. Micronutrient research and sustainable agricultural productivity. Journal of the Indian Society of Soil Science 44:563-581.

Takkar, P. N., I. M. Chhibba, and S. K. Mehta. 1989. Twenty years of coordinated research on micronutrients in soils and plants (1967-1987) (Bulletin No.1). Bhopal, India: Indian Institute of Soil Science.

Wani, S. P., P. Pathak, L. S. Jangawad, H. Eswaran, and P. Singh. 2003. Improved management of Vertisols in the semiarid tropics for increased productivity and soil carbon sequestration. Soil Use and Management 19:217-222. 
Copyright of Communications in Soil Science \& Plant Analysis is the property of Taylor \& Francis Ltd and its content may not be copied or emailed to multiple sites or posted to a listserv without the copyright holder's express written permission. However, users may print, download, or email articles for individual use. 